\title{
Meso-scale variations in diet composition of little auk chicks in north-west Spitsbergen
}

\author{
Rafał Boehnke (10), Kaja Balazy (1) ${ }^{a}$, Dariusz Jakubas $\mathbb{1 0}^{\mathrm{b}}$, Katarzyna Wojczulanis-Jakubas ${ }^{\mathrm{b}}$ \\ \& Katarzyna Błachowiak-Samołyk ${ }^{\mathrm{a}}$
}

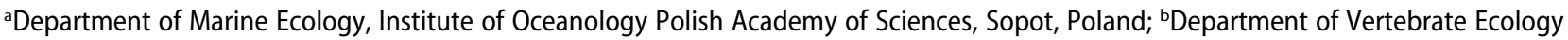
and Zoology, University of Gdańsk, Gdańsk, Poland

\begin{abstract}
Colonial seabirds from neighbouring breeding aggregations may share foraging grounds or utilize different areas in order to decrease the competition over food resources. In our study, we present the meso-scale variations in the diet composition of zooplanktivorous little auk chicks (Alle alle), based on samples collected over two years in two neighbouring colonies (Aasefjellet and Magdalenefjorden) located in north-west Spitsbergen, Svalbard. Although the colonies are situated only $10 \mathrm{~km}$ apart, they differ in geographical features (in-fjord vs. coastal). The main findings of our study were significant inter-colony and inter-year differences in the total abundance of diet items and in abundance of particular components. The open-sea species Themisto abyssorum was more abundant in the diet of chicks from Aasefjellet, situated in the outer coast. Another open-sea species, Calanus hyperboreus was also characteristic for this colony but only in the first year of study. On the other hand, the ice-associated amphipod Apherusa glacialis was regularly observed in the diet of little auk chicks from the Magdalenefjorden colony, which is located closer to the marginal ice zone. The differences observed in the diet composition of birds from the two neighbouring sites may indicate that two colonies of birds have at least partly separate foraging areas. Our results could also suggest flexibility in the little auk's foraging behaviour that enables it to adapt to local feeding conditions. Thus, our study significantly contributes to the deeper understanding of little auks' feeding strategies in the changing environment of northern Spitsbergen.
\end{abstract}

\section{KEYWORDS}

Dovekie; Svalbard; colony; zooplankton; diet composition; Alle alle

\section{ABBREVIATIONS}

HACA: hierarchical cluster analysis; MIZ: marginal ice zone; PERMANOVA: permutational multivariable analysis of variance; SIMPER: similarity percentage breakdown; CGD: "Calanus glacialis dominated" group; OID: group with species other than C. glacialis constituting over half of the sample content; NDD: "no defined dominant" group
Breeding seabirds are restricted by their colony location. To provide offspring with sufficient food in a reasonable period of time, they exploit the foraging areas located as close to the breeding colony as possible (Davies et al. 2012). Nevertheless, because the distribution of food resources often varies annually (e.g., Hovinen et al. 2014) as well as within the breeding season (e.g., Ashmole's halo effect [Ashmole 1963; Birt et al. 1987; Elliott et al. 2009]), seabird parents usually need to cover a great distance from their colony to collect enough food and/or to collect food of appropriate quality (Amélineau et al. 2016). As a consequence, birds from different colonies may meet at a distant, common foraging ground and exploit the same food resources (Ainley et al. 2004; Jakubas \& Wojczulanis-Jakubas 2011). On the other hand, birds from neighbouring colonies may forage in completely different zones. There is growing evidence for space partitioning among colonial seabirds. For instance, petrels (Pelecanoides georgicus and P. urinatrix) from neighbouring colonies on the sub-Antarctic island of South Georgia have been reported to forage in exclusive areas that are not necessarily located close to their breeding colony (Bocher et al. 2000). There is also evidence for partial and/or complete spatial segregation in shags (Phalacrocorax aristotelis) in colonies on South Georgia (Wanless \& Harris 1993) and among some penguin species in separate colonies situated only $2-2.5 \mathrm{~km}$ apart on New Island, in the Falkland Islands (Masello et al. 2010). Although it is still not clear why such space partitioning occurs among birds, it is likely to be influenced by memory (individuals return to the previously "successful" location), local enhancement (other birds at sea follow the "successful" ones), information centre effect (when "uninformed" birds follow "successful" birds from their colonies [Wakefield et al. 2013]) and/or avoidance of competition.

Inspired by all these findings, we examined food samples of the little auk (Alle alle) collected in two north-west Spitsbergen colonies-Aasefjellet and Magdalenefjorden-which are located $10 \mathrm{~km}$ apart. The little auk is a small, zooplanktivorous seabird that breeds colonially. It is considered to be the most numerous alcid in the Arctic (Stempniewicz 2001). The little auk has one of the highest mass-specific 
metabolic rates of all seabirds (Gabrielsen et al. 1991; Konarzewski et al. 1993). To satisfy their high energy demands (e.g., Konarzewski et al. 1993), the birds focus on energy-rich planktonic organisms associated with cold Arctic waters-mainly large copepods, such as Calanus glacialis and/or C. hyperboreus. Less frequently, but regularly, they also consume smaller and less-nutritional food items, such as C. finmarchicus, which is associated with Atlantic waters (Mehlum \& Gabrielsen 1993; Weslawski et al. 1999; Planque \& Batten 2000; Pedersen \& Falk 2001; Karnovsky et al. 2003; Weslawski et al. 2006; Wojczulanis et al. 2006; Jakubas et al. 2007; Jakubas \& Wojczulanis-Jakubas 2011; Hovinen et al. 2014). Moreover, little auks from some colonies are able to fly up to $130 \mathrm{~km}$ (Jakubas et al. 2013) to forage on the sympagic amphipod Apherusa glacialis occurring at the MIZ.

Despite the high prevalence of these zooplankters in little auks' diets, some differences in composition (percentage of the main items and contribution to supplementary components) are regularly reported (e.g., Karnovsky et al. 2003; Falk-Petersen et al. 2009; Harding et al. 2008; Jakubas et al. 2007; Harding et al. 2009; Kwasniewski et al. 2010; Jakubas et al. 2014; Boehnke et al. 2015; Jakubas, Iliszko et al. 2016; Jakubas, Wojczulanis-Jakubas et al. 2016). These differences could be caused by the partitioning of available foraging grounds (in terms of geographical location and/or environmental characteristics) among birds from different colonies.

The two colonies in which we examined the little auk's diet are separated by $10 \mathrm{~km}$. This distance is within the range of little auk's regular foraging flights (Grémillet et al. 2004), which have a median of $126 \mathrm{~km}$, as estimated from GPS tracking in Magdalenefjorden (Jakubas et al. 2013). Given the high costs of these flights (Gabrielsen et al. 1991; Konarzewski et al. 1993), little auks are expected to forage exclusively within a "cost-effective" distance from the breeding colony (Kwasniewski et al. 2010). As a consequence, individuals from both colonies can utilize the same foraging grounds and should have similar diets. On the other hand, some differences in diet composition of birds could be caused by their tendency to avoid competition for food resources. Furthermore, the fact that one colony is located in the MIZ and the other is sea-exposed might influence the direction of the foraging flights and favour the segregation of feeding grounds. Since the Magdalenefjorden colony was situated closer to the MIZ than Aasefjellet (60 vs. $90 \mathrm{~km}$ in 2009 and 120 vs. $140 \mathrm{~km}$ in 2010; Fig. 1), ice-associated fauna should have appeared more frequently in the diets of birds from this colony. In contrast, the Aasefjellet colony has a more outer-coast location than the inside-fjord colony in Magdalenefjorden (Fig. 1). We may therefore expect a higher frequency of prey items living in waters outside fjords, such as Themisto abyssorum (Koszteyn et al. 1995)

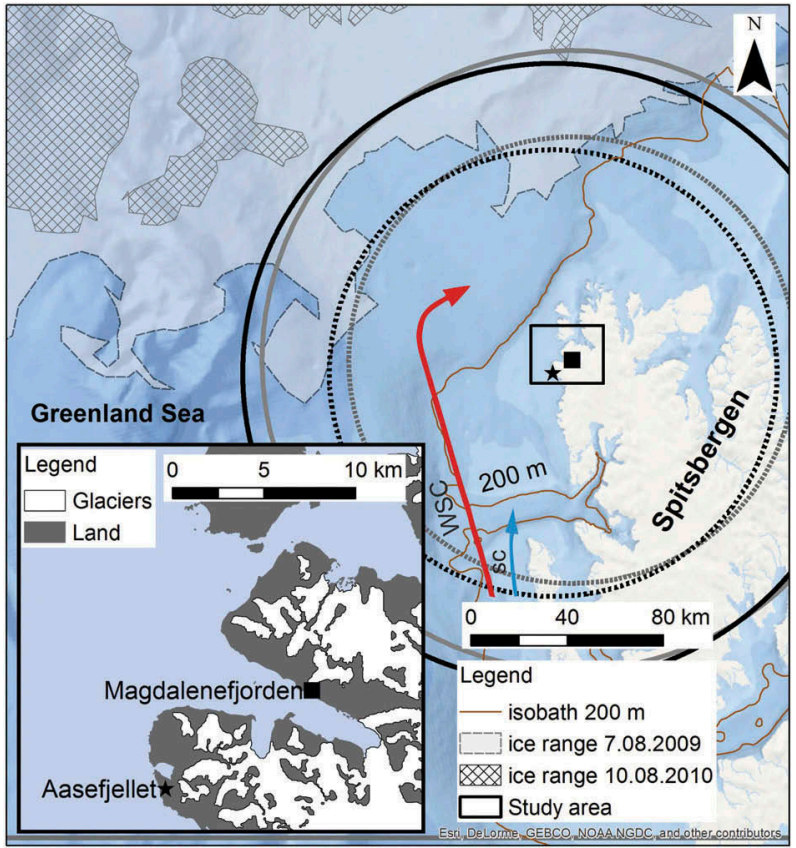

Figure 1. The study area of little auk colonies in north-west Spitsbergen: Magdalenefjorden (square) and Aasefjellet (star). Large and smaller dashed circles represent 75 and 25 percentiles of foraging flights range of GPS-equipped little auks from Magdalenefjorden (Jakubas et al. 2013). Potential ranges of foraging flights of birds from Aasefjellet (marked in black) and Magdalenefjorden (in grey). Isobath: $200 \mathrm{~m}$ indicates the range of the shelf zone. The warm West Spitsbergen Current is abbreviated to WSC and the cold Sørkapp Current to SC.

and Calanus hyperboreus (Hirche et al. 2006), in the diet of birds breeding in Aasefjellet.

\section{Material and methods}

\section{Study area}

Diet samples were collected in 2009 and 2010 in two breeding colonies of little auks, in Aasefjellet $\left(79^{\circ} 32^{\prime} \mathrm{N}\right.$, $10^{\circ} 45^{\prime} \mathrm{E}$ ) and in Magdalenefjorden, on the Alkekongen slopes $\left(79^{\circ} 35^{\prime} \mathrm{N}, 11^{\circ} 05^{\prime} \mathrm{E}\right.$; Fig. 1). The distance between the Magdalenefjorden colony (which faces the south) and Aasefjellet colony (facing the west) is $10 \mathrm{~km}$. The foraging areas of birds from these colonies are influenced by the warm Atlantic waters of the West Spitsbergen Current and the cold Arctic waters of the coastal Sørkapp Current, which converge, mix and exchange, forming the hydrographical Arctic front along the West Spitsbergen Shelf (Saloranta \& Svendsen 2001; Cottier et al. 2005; Nilsen et al. 2008).

\section{Diet sampling and laboratory analyses}

The samples were collected at roughly the same time in the two colonies, between the third and fourth week of the little auk chicks' life: 9-10 August 2009 and 11-12 
August 2010 in Magdalenefjorden; 9 August 2009 and 7-8 August 2010 in Aasefjellet. The little auk's phenology was established based on median hatching dates in Magdalenefjorden: 17 July in 2009 (Jakubas \& Wojczulanis-Jakubas 2011) and 16 July in 2010 (Jakubas, Wojczulanis-Jakubas et al. 2016). The phenologies of birds in the Aasefjellet and Magdalenefjorden colonies were assumed to be the same on account of their proximity. Snow melt onset is unlikely to differ between the colonies, which is the main factor that influences the timing of egg laying for little auks (Moe et al. 2009). To collect the food samples, we captured adults with full gular pouches (while returning from the foraging grounds to their colony) by a mist-net and/or noose carpet spread in the colony area. The contents of the gular pouch (a special sac under the bill to transport food for chicks) were gently scooped out with a small plastic spoon, placed in a separate plastic container and preserved in a $4 \%$ solution of formaldehyde diluted with filtered salt (sea) water. The birds were released unharmed after 5-10 min. of handling. In total, $93 \mathrm{sam}-$ ples were collected (Table 1). The taxonomic content of the samples was analysed in the laboratory, following the procedures described by Kwasniewski et al. (2010).

\section{Data analyses}

The diet in both colonies was examined considering a total abundance of diet items, as well as abundance of the most frequent items. Dissimilarities in the samples were also compared. To investigate factors affecting the total abundance of diet items, distance-based PERMANOVA (Anderson 2001) was used. As categorical factors, the following predictors were used: colony, year and the interaction colony $\times$ year. To assess contribution of the most frequent prey items to the dissimilarity between samples, the SIMPER procedure was used based on a Bray-Curtis dissimilarity matrix (Clarke 1993). To investigate factors affecting abundance of these particular prey items (i.e., contributing $\geq 5 \%$ to overall dissimilarity), two-way PERMANOVA with colony, year and interaction between the two was used. For prey species with significant interaction effect in two-way PERMANOVA, one-way PERMANOVA with a categorical factor (season and colony combined) was performed. Both the analyses -two-way PERMANOVA and one-way PERMANOVA -were based on a Bray-Curtis resemblance matrix. For

Table 1. Frequency of particular types of little auk food samples collected in Magdalenefjorden and Aasefjellet colonies in 2009 and 2010.

\begin{tabular}{lcccccc}
\hline & \multicolumn{2}{c}{ Magdaleneforden } & & Aasefjellet & & Total \\
\cline { 2 - 3 } Food sample type & 2009 & 2010 & & 2009 & 2010 & $\mathrm{~N}$ \\
\hline $\begin{array}{l}\text { Calanus glacialis dominated } \\
\text { (CGD) }\end{array}$ & $37 \%$ & $10 \%$ & $23 \%$ & $30 \%$ & 30 \\
$\begin{array}{c}\text { Other item dominated } \\
\quad(O I D)\end{array}$ & $32 \%$ & $32 \%$ & $24 \%$ & $12 \%$ & 41 \\
No defined dominant (NDD) & $23 \%$ & $23 \%$ & $32 \%$ & $23 \%$ & 22 \\
\hline
\end{tabular}

all data the fourth root transformation was used, and each analysis was tested using 9999 random permutations. PERMANOVA and SIMPER analyses were conducted in PERMANOVA + add-on to Primer version 7 software (Plymouth Marine Laboratory, Plymouth, UK; Clarke \& Warwick 2001).

Based on the prey item dominance in a sample (over $50 \%$ of identified taxa in total sample abundance), samples were categorized into one of the following types: (1) "Calanus glacialis dominated" (CGD), where Calanus glacialis constituted over half of the sample content; (2) "other item dominated" (OID), where species other than C. glacialis constituted over half of the sample content; (3) "no defined dominant" (NDD), where none of the identified taxa exceeded half of the sample content.

The proportion of different types of diet samples between colonies was analysed with a $G$ test. To examine similarities between the compositions among considered types of diet samples, HACA was used on a data matrix of all little auk food items abundances. Analyses were based on Bray-Curtis similarities of log-transformed data $\left[\mathrm{x}^{\prime}=\log (\mathrm{x}+1)\right]$, which downplays any species/taxa with very high abundance/share, whilst retaining the basic quantitative information (Clarke \& Warwick 2001). In HACA analyses only clusters with bootstrap probability over $95 \%$ were considered. Cluster and bootstrap probability analyses were run using Primer version 7.0.

\section{Results}

Two-way PERMANOVA revealed that the abundance of all prey items combined was affected significantly by colony $\left(\mathrm{F}_{1}=4.95, p<0.001\right)$ and years $\left(\mathrm{F}_{1}=5.12, p<0.001\right)$. The effects of interaction between colony $\times$ year were not significant $\left(\mathrm{F}_{1}=1.83 p=0.12\right)$. Aasefjellet was characterized by a higher number of diet items (median $=820$ ) than Magdalenefjorden (median $=588$ ). The first year of the study was characterized by a higher abundance of diet items (median = 907) than the year 2010 (median $=474$ ). SIMPER revealed the following prey items contributing the most $(\geq 5 \%)$ to overall dissimilarity in abundance of prey items in little auk chicks' meals: three copepod species in the genus Calanus-C. glacialis, C. finmarchicus and C. hyperboreus-and the amphipods Themisto abyssorum and Apherusa glacialis.

Two-way PERMANOVA for the abundance of prey items mostly contributing to overall dissimilarity revealed a significant effect of colony on A. glacialis $\left(\mathrm{F}_{1}=12.66, p<0.001\right.$, with the higher abundance in Magdalenefjorden) and T. abyssorum $\left(\mathrm{F}_{1}=10.19\right.$, $p=0.001$, with the higher abundance in Aasefjellet). A significant effect of year was found on C. hyperboreus $\left(\mathrm{F}_{1}=40.50, p<0.001\right.$, with the higher abundance 
in 2009). An important effect of interaction season $x$ colony was found only for C. hyperboreus $\left(\mathrm{F}_{1}=9.62\right.$, $p<0.001)$. One-way PERMANOVA with colony $x$ year factor revealed noticeable differences $\left(\mathrm{F}_{3}=16.10\right.$, $p=0.001$ ) with a significantly higher abundance of this copepod in Aasefjellet's food samples from 2009 compared to other studied years and colonies. Neither colony nor year nor the interaction colony $\times$ year affected the abundance of $C$. glacialis and $C$. finmarchicus significantly (PERMANOVA all $p>0.05)$.

The OID type food samples were the most frequent $(44 \%)$ in the analysed material. The CGD and NDD sample types constituted $32 \%$ and $24 \%$ of all studied little auks' diet samples, respectively (Table 1). There were no significant differences in the proportions of various diet samples types between years and colonies ( $G$ test, $\mathrm{G}_{6}=8.05, p>0.05$ ).

Among the OID samples, a subgroup dominated by T. abyssorum (D, Fig. 3) was the most frequently observed (29\%), with this zooplankter constituting $62 \%$ of all diet items abundance. The second subgroup among the OID type was dominated by the sympagic A. glacialis, which was regularly observed in Magdalenefjorden and only once in Aasefjellet (A, Fig. 3). This item constituted an exceptional diet component, as it made up almost the whole samples: mean contribution was $97 \%$ of the total prey items recorded in subgroup A (Fig. 3). The third subgroup in the OID category was dominated by C. hyperboreus, whose mean contribution was about $70 \%$ of all diet items in this subgroup (E, Fig. 3). The other

\section{Calanus glacialis dominated samples}

A
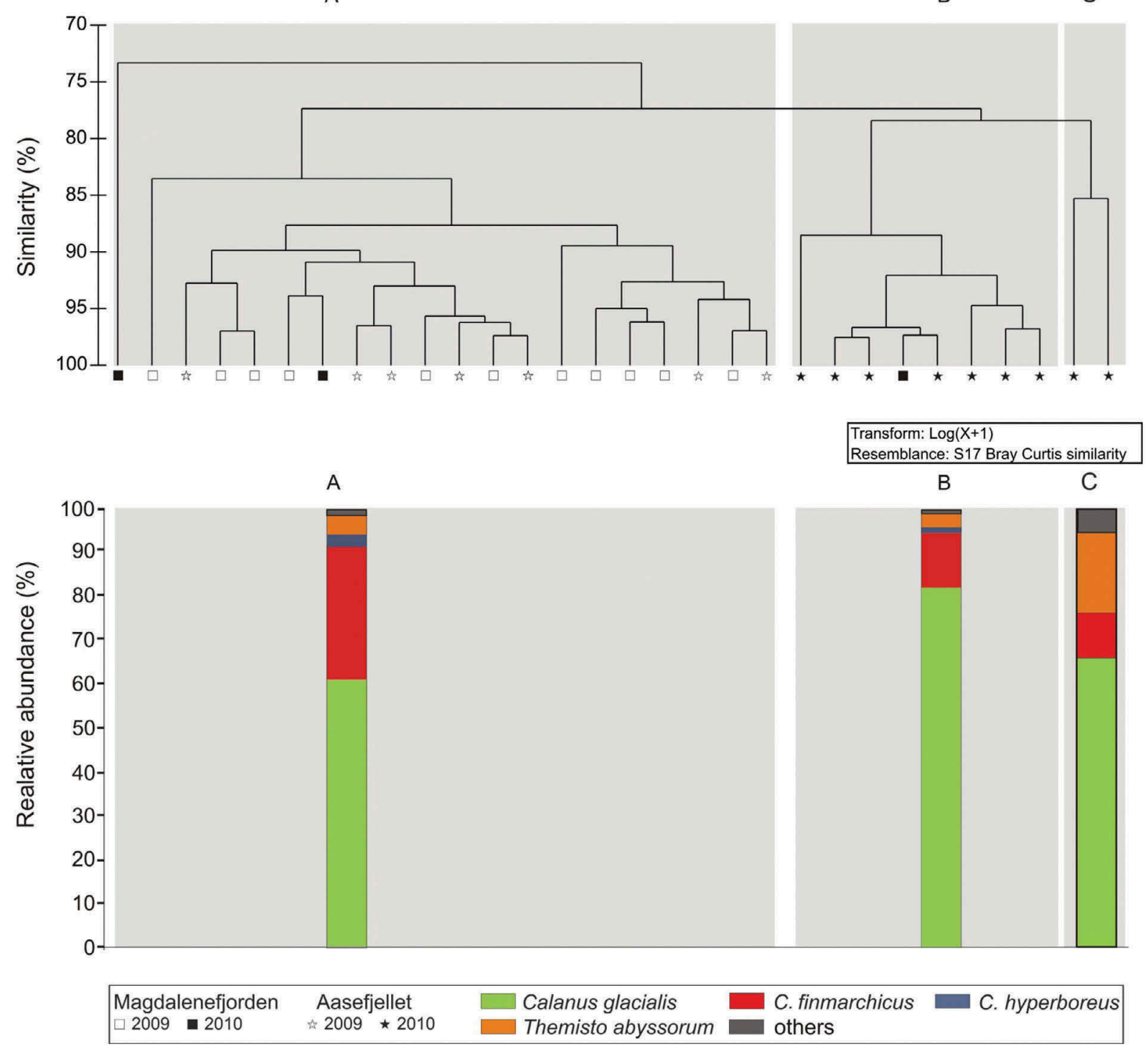

Figure 2. Cluster analysis for samples of the "Calanus glacialis dominated" (CGD) type from Aasefjellet (stars) and Magdalenefjorden (squares) colonies, years: 2009 (white) 2010 (black). The main clusters are denoted with letters a-c. Barplots show the proportion of the items in detail provided under the tree graph, separately for each main cluster. 


\section{Other item dominated samples}
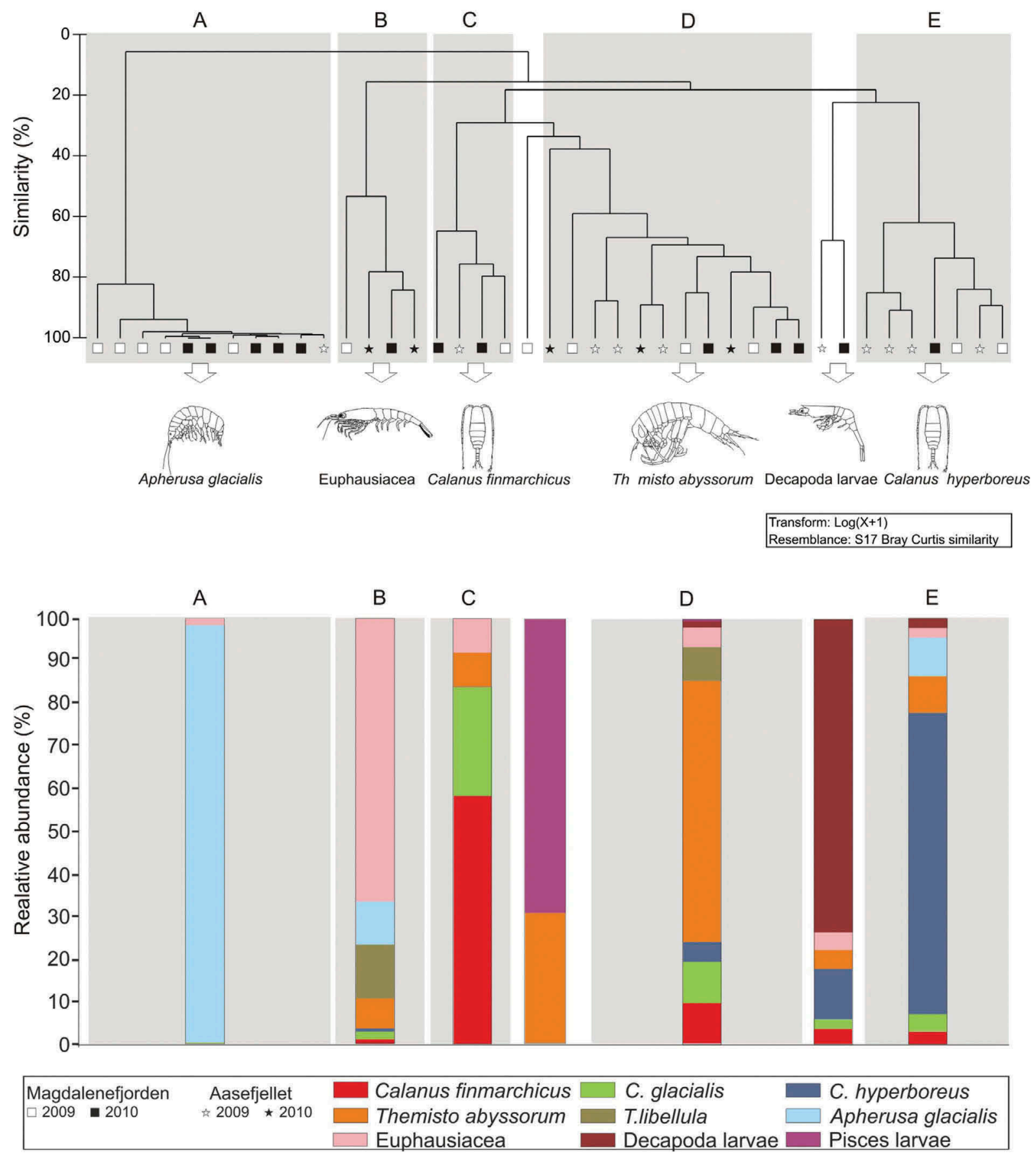

Figure 3. Cluster analysis for samples of the "other item dominated" (OID) type from Aasefjellet (stars) and Magdalenefjorden (squares) colonies, years: 2009 (white) 2010 (black). Letters under the $\mathrm{x}$ axis (a-g) indicate subgroups of samples dominated by: Apherusa glacialis (a); Euphausiacea (b); Calanus finmarchicus (c); Themisto abyssorum (d); Decapoda larvae (e); C. hyperboreus (f). Schemes under each subgroup of samples illustrate the dominant species in diet item abundance. Barplots show the proportion of the items in detail provided under the tree graph, for each main subgroup separately.

subgroups from the OID sample types were dominated by Euphausiacea and C. finmarchicus ( $65 \%$ and $55 \%$ contribution in abundance in subgroups B and C shown in Fig. 3, respectively). The rarest among the OID samples type were two dominated by larval stages of Decapoda (mean share of $73 \%$ of the total prey items) and one with the highest contribution (69\%) of Pisces larvae (Fig. 3).
Samples of the CGD type were divided into three subgroups in the hierarchical cluster analysis (Fig. 2). In subgroup $B$, represented mainly by samples from Aasefjellet from 2010, the highest contribution of $C$. glacialis was observed (83\%). The remaining subgroups were characterized by a lower abundance of this prey item: 61 and $66 \%$ in subgroup $A$ and $C$, respectively (Fig. 2). Hierarchical cluster analysis did 
not distinguish any significant subgroups within NDD type samples.

\section{Discussion}

This is the first study to compare the diet composition of little auks chick on a meso-scale, i.e., between two neighbouring colonies. Our study was conducted during two consecutive years in north-west Spitsbergen: Magdalenefjorden, regularly monitored since 2007 (Kwasniewski et al. 2010), and the newly investigated Aasefjellet. Diet composition of birds from the Magdalenefjorden colony between 2009 and 2010 was partly presented by Kidawa et al. (2015), Hovinen et al. (2014), Jakubas, Wojczulanis-Jakubas et al. (2016) and Boehnke et al. (2015).

Our research revealed substantial inter-colony differences in the abundance of diet items. A higher number of diet items were observed in the Aasefjellet colony in comparison to the colony in Magdalenefjorden. In the Aasefjellet colony, there was a higher frequency of CGD samples (characterized by high numbers of individuals) and very low frequency of samples predominated by Apherusa glacialis (characterized by low number of items per sample). Moreover, the number of prey items differed significantly between years, which may have been caused by changes in inter-year oceanographic conditions that generally influence the availability of particular zooplankters (Trudnowska et al. 2015).

Our results confirm the important role of the sympagic amphipod Apherusa glacialis for the Magdalenefjorden colony: it constituted from 17 to $24 \%$ of all analysed diet material from this site. Previous research in this region showed that $5 \%$ of samples (two samples) contained exclusively A. glacialis in 2007 (Kwasniewski et al. 2010), while 10\% of samples (seven samples) described as "Apherusa glacialis type" were reported one year later (Jakubas et al. 2011). The presence of this amphipod is likely to be conditioned by the changing sea-ice range in a given year. According to the research of Scott et al. (1999), these ice-associated amphipods are very rich in lipids, which constitute about $51 \%$ of dry mass.

It is known that little auks are able to reach distant feeding grounds in the Arctic Ocean, where multi-year ice with sympagic fauna prevails, e.g., East Greenland (Fort et al. 2010; Amélineau et al. 2016). The distance from Magdalenefjorden to the MIZ in $2010(120 \mathrm{~km})$ was closer to the median value of the foraging range of GPS-tracked birds (median $=126 \mathrm{~km}$; Jakubas et al. 2013) and it was lower than the distance from the MIZ to Aasefjellet $(140 \mathrm{~km})$. The almost complete absence of A. glacialis in the diet of birds from Aasefjellet (Fig. 3) implies that even small differences in distances between colonies and foraging grounds seem to influence the possibility of feeding on ice-associated fauna. This finding may be explained by the little auk's propensity to forage within a cost-effective distance from its colony, since farther flights are more energy demanding (Gabrielsen et al. 1991). This has also been confirmed by the almost complete absence of this amphipod in the diet of birds from other Svalbard colonies located south of the studied ones: Kongsfjorden (Seifert 2007), Isfjorden (Steen et al. 2007; Vogedes et al. 2014) and Hornsund (Jakubas et al. 2007; Kwasniewski et al. 2010; Boehnke et al. 2015).

A relatively large number of samples containing $A$. glacialis in the northernmost of little auk colonies in Spitsbergen-Magdalenefjorden-could be explained by the foraging birds' ability to memorize successful locations, such as the MIZ (Wakefield et al. 2013). We should also take into account that little auks adopt a bimodal foraging strategy, altering short and long-foraging trips (Steen et al. 2007). The shorter types of trips are typical for nearby locations and their main purpose is to collect food for chicks, while during the longer ones adults rest and forage in more distant locations, such as the MIZ, in order to collect food for both themselves and their chicks (Jakubas et al. 2012; Welcker et al. 2012). Given the lower frequency of long trips to more distant locations, such as the MIZ, in the bimodal strategy, it is less probable to sample birds returning from long trips compared to ones returning from short trips.

Another frequent zooplankton item-Themisto abyssorum-was observed among the prey of the coastal colony at Aasefjellet. In Iceland and Hudson Bay, this pelagic amphipod is characteristic of opensea sub-Arctic waters (Estrada et al. 2012; Gislason \& Silva 2012). The presence of this amphipod in the colony located nearer to the shelf seemed to confirm this species' preference for water outside the fjords; a recent study also confirmed the dominance of this amphipod in waters outside Kongsfjorden (Dalpadado et al. 2016). Themisto abyssorum dominated samples from Aasefjellet indicate that birds from this region forage in open-sea waters, possibly close to their colony area. Themisto abyssorum was also found in samples taken from Magdalenefjorden (dominant in $50 \%$ of samples in subgroup D among OID type), which suggests that little auks from this colony can utilize the open-sea waters and possibly share areas with the birds from Aasefjellet. These results are consistent with the previous studies of Kwasniewski et al. (2010), who reported a considerable contribution (12\%) of T. abyssorum in the diet of little auk chicks from Magdalenefjorden in 2007. Furthermore, this item was reported in the diet of little auks from the Bjørndalen colony, in Isfjorden, with a sizeable contribution (17.6\%) of total diet items in samples, which were characterized by a 
relatively low share of copepod C. hyperboreus (Steen et al. 2007). This amphipod is regarded as a rather low-energy food item and its distribution is connected to the influx of Atlantic Water (Stempniewicz et al. 2007). Such a wide distribution of T. abyssorum in little auk chicks' diet could also suggest offshore or opportunistic feeding behaviour of the birds from both colonies.

The abundance of Calanus hyperboreus was significantly influenced by year and interaction colony $x$ year. This prey item was found mainly in samples from Aasefjellet in 2009 (group E in Fig. 3). This copepod was previously reported as a component of little auk chicks' diet in the Magdalenefjorden colony, with a $10-12 \%$ contribution to total diet item abundance in 2007 and 2008, respectively (Kwasniewski et al. 2010; Jakubas et al. 2011). During previously mentioned studies from the year 2008, eight samples described as C. hyperboreus type were observed. Calanus hyperboreus was also an important diet item for birds from the Bjørndalen colony (Isfjorden); samples were distinguished based on the share of C. hyperboreus with 25\% criteria (Steen et al. 2007 ) and $21 \%$ of collected samples belonged to this type. This item, regarded as a true Arctic inhabitant (Hirche 2013), prefers deeper regions outside the shelf in waters near Svalbard (Hirche et al. 2006). According to Hagen and Auel (2001) this species accumulates larger amounts of fatty acids than $C$. glacialis and C. finmarchicus. This copepod therefore seems to be a very nourishing source of lipids for little auk chicks. Contrary to our study, in Greenland, this species is more available for the little auks that forage near to the shore (Karnovsky et al. 2010; Amélineau et al. 2016).

In conclusion, our study reveals some significant inter-colony differences in the composition of little auks chicks' diet at a meso-scale level $(10 \mathrm{~km})$, confirming our hypothesis about the differences between chicks' diets. Our main finding was the absence of the iceassociated amphipod Apherusa glacialis in the diet of chicks from the southern colony, located further from the MIZ. The open-sea species T. abyssorum was found in higher abundance in the gular pouches of the birds from open-sea colony at Aasefjellet. The second species characteristic of open waters - C. hyperboreus was also observed in higher numbers in parent birds from Aasefjellet but only in the first year of study.

The observed inter-colony differences in the diet composition of these birds suggest at least partial segregation of foraging grounds that could be caused by the flight costs from the colony to the feeding areas. The differences in diet composition between the two colonies reveal that the little auk is able to efficiently utilize the available food resources. This study, along with previous reports from Magdalenefjorden, broaden our knowledge about the progressive oceanographic changes occurring in Spitsbergen. Further studies with the use of additional methods (e.g., GPS tracking) are required in order to fully comprehend intra-specific meso-scale differences in the foraging behaviour of little auk.

\section{Acknowledgements}

We would like to thank Lech Iliszko, Wojciech Iliszko, Małgorzata Jakimiak and Katarzyna Pińska for their help in the fieldwork. RB would like to thank Juita Śledziewska for her help with writing this paper. KB has been supported as a $\mathrm{PhD}$ student by the Centre for Polar Studies, Krajowe Naukowe Ośrodki Wiodące-Leading National Research Centre, Poland.

\section{Disclosure statement}

No potential conflict of interest was reported by the authors.

\section{Funding}

This study was supported by a grant from Norway through the Norwegian Financial Mechanism, project no. PNRF234-AI-1/07 (ALKEKONGE), the National Science Foundation (OPP grant no. 0612504). This research received substantial support from the Ministry of Science and Higher Education, Republic of Poland through projects 3088/SEAPOP/2014/2 and 3605/SEAPOP/2016/2 for the years 2014-15 and 2016-20, respectively; Polska Akademia Nauk (3088/SEAPOP/2014/2); Polska Akademia Nauk (PNRF-234-AI-1/07 [ALKEKONGE]).

\section{ORCID}

Rafał Boehnke (1D http://orcid.org/0000-0001-8349-818X Kaja Balazy (D) http://orcid.org/0000-0001-5377-3574

Dariusz Jakubas (D) http://orcid.org/0000-0002-1879-4342

\section{References}

Ainley D.G., Ribic C.A., Ballard G., Heath S., Gaffney I., Karl B.J., Barton K.J., Wilson P.R. \& Webb S. 2004. Geographic structure of Adélie penguin populations: overlap in colony-specific foraging areas. Ecological Monographs 74, 159-178.

Amélineau F., Grémillet D., Bonnet D., Le Bot T., Fort J. \& Peter H.-U. 2016. Where to forage in the absence of sea ice? Bathymetry as a key factor for an Arctic seabird. PLoS One 11(7), e0157764, doi: 10.1371/journal. pone. 0157764

Anderson M.J. 2001. A new method for non-parametric multi-variate analysis of variance. Austral Ecology 26, 32-46.

Ashmole N.P. 1963. The regulation of numbers of tropical oceanic birds. Ibis 103b, 458-473.

Birt V.L., Birt T.P., Goulet D., Cairns D.K. \& Montevecchi W.A. 1987. Ashmole's halo: direct evidence for prey depletion by a seabird. Marine Ecology Progress Series 40, 205-208.

Bocher P., Cherel Y. \& Hobson K.A. 2000. Complete trophic segregation between South Georgian and 
common diving petrels during breeding at Iles Kerguelen. Marine Ecology Progress Series 208, 249-264.

Boehnke R., Gluchowska M., Wojczulanis-Jakubas K., Jakubas D., Karnovsky N.J., Walkusz W., Kwasniewski S. \& Błachowiak-Samołyk K. 2015. Supplementary diet components of little auk chicks in two contrasting regions on the west Spitsbergen coast. Polar Biology 38, 261-267.

Clarke K.R. 1993. Non-parametric multivariate analyses of changes in community structure. Australian Journal of Ecology 18, 117-143.

Clarke K.R. \& Warwick R.M. 2001. Change in marine communities: an approach to statistical analysis and interpretation. Plymouth, UK: Primer-E Ltd.

Cottier F., Tverberg V., Inall M., Svendsen H., Nilsen F. \& Griffiths C. 2005. Water mass modification in an Arctic fjord through cross-shelf exchange: the seasonal hydrography of Kongsfjorden, Svalbard. Journal of Geophysical Research-Oceans 110, C12005, doi: 10.1029/ 2004JC002757

Dalpadado P., Hop H., Rønning J., Pavlov V., Sperfeld E., Buchholz F., Rey A. \& Wold A. 2016. Distribution and abundance of euphausiids and pelagic amphipods in Kongsfjorden, Isfjorden and Rijpfjorden (Svalbard) and changes in their relative importance as key prey in a warming marine ecosystem. Polar Biology 39, 17651784.

Davies N., Krebs J. \& West S. 2012. Introduction to behavioral ecology. 4th edn. Hoboken: John Wiley \& Sons.

Elliott K.H., Woo K.J., Gaston A.J., Benvenuti S., Dall'Antonia L. \& Davoren G.K. 2009. Central-place foraging in an Arctic seabird provides evidence for Storer-Ashmole's halo. The Auk 126, 613-625.

Estrada R., Harveya M., Gosselin M., Starr M., Galbraitha P.S. \& Straneoc F. 2012. Late-summer zooplankton community structure, abundance, and distribution in the Hudson Bay system (Canada) and their relationships with environmental conditions, 2003-2006. Progress in Oceanography 101, 121-145.

Falk-Petersen S., Mayzaud P., Kattner G. \& Sargent J. 2009. Lipids and life strategy of Arctic Calanus. Marine Biology Research 5, 18-39.

Fort J., Cherel Y., Harding A.M.A., Welcker J., Jakubas D., Steen H., Karnovsky N.J. \& Grémillet D. 2010. Geographic and seasonal variability in the isotopic niche of little auks. Marine Ecology Progress Series 414, 293-302.

Gabrielsen G.W., Taylor J.R.E., Konarzewski M. \& Mehlum M. 1991. Field and laboratory metabolism and thermoregulation in dovekies (Alle alle). The Auk 108, 71-78.

Gislason A. \& Silva T. 2012. Abundance, composition and development of zooplankton in the Subarctic Iceland Sea in 2006, 2007 and 2008. ICES Journal of Marine Science 69, 1263-1276.

Grémillet D., Dell'Omo G., Ryan P.G., Peters G., RopertCouderty Y. \& Weeks S.J. 2004. Offshore diplomacy, or how seabirds mitigate intra-specific competition: a case study based on GPS tracking of Cape gannets from neighbouring colonies. Marine Ecology Progress Series 268, 265-279.

Hagen W. \& Auel H. 2001. Seasonal adaptations and the role of lipids in oceanic zooplankton. Zoology 104, 313326.

Harding A.M.A., Egevang C., Walkusz W., Merkel F., Blanc S. \& Grémillet D. 2009. Estimating prey capture rates of a planktivorous seabird, the little auk (Alle alle), using diet, diving behaviour, and energy consumption. Polar Biology 32, 785-796.

Harding A.M.A., Hobson K.A., Walkusz W., Dmoch K., Karnovsky N.J., Van Pelt T.I. \& Lifjeld J.T. 2008. Can stable isotope $\left(\delta^{13} \mathrm{C}\right.$ and $\left.\delta^{15} \mathrm{~N}\right)$ measurements of little auk Alle alle adults and chicks be used to track changes in High-Arctic marine foodwebs? Polar Biology 31, 725-733.

Hirche H.-J. 2013. Long-term experiments on lifespan, reproductive activity and timing of reproduction in the Arctic copepod Calanus hyperboreus. Marine Biology 160, 2469-2481.

Hirche H.J., Muyakshin S., Klages M. \& Auel H. 2006. Aggregation of the Arctic copepod Calanus hyperboreus over the ocean floor of the Greenland Sea. Deep Sea Research Part I: Oceanographic Research Papers 53, 310-320.

Hovinen J.H., Wojczulanis-Jakubas K., Jakubas D., Hop H., Berge J., Kidawa D., Karnovsky N.J. \& Steen H. 2014. Fledging success of little auks in the High Arctic: do provisioning rates and the quality of foraging grounds matter? Polar Biology 37, 665-674.

Jakubas D., Iliszko L.M., Strøm H., Darekci M., Jerstad K. Stempniewicz L.. 2016. Foraging behavior of a HighArctic zooplanktivorous alcid, the little auk, at the southern edge of its breeding range. Journal of Experimental Marine Biology and Ecology 475, 89-99.

Jakubas D., Iliszko L., Wojczulanis-Jakubas K. \& Stempniewicz L. 2012. Foraging by little auks in the distant marginal sea ice zone during the chick-rearing period. Polar Biology 35, 73-81.

Jakubas D., Trudnowska E., Wojczulanis-Jakubas K., Iliszko L., Kidawa D., Darecki M., Błachowiak-Samołyk K. \& Stempniewicz L. 2013. Foraging closer to the colony leads to faster growth in little auks. Marine Ecology Progress Series 489, 263-278.

Jakubas D., Wojczulanis K. \& Walkusz W. 2007. Response of dovekie to changes in food availability. Waterbirds 30 , 421-428.

Jakubas D. \& Wojczulanis-Jakubas K. 2011. Subcolony variation in phenology and breeding parameters in little auk Alle alle. Polar Biology 34, 31-39.

Jakubas D., Wojczulanis-Jakubas K., Boehnke R., Kidawa D., Błachowiak-Samołyk K. \& Stempniewicz L. 2016. Intra-seasonal variation in zooplankton availability, chick diet and breeding performance of a High Arctic planktivorous seabird. Polar Biology 39, 1547-1561.

Jakubas D., Wojczulanis-Jakubas K., Iliszko L., Darecki M. \& Stempniewicz L. 2014. Foraging strategy of the little auk Alle alle throughout breeding season - switch from unimodal to bimodal pattern. Journal of Avian Biology 45, 551-560.

Karnovsky N.J., Harding A., Walkusz W., Kwasniewski S., Goszczko I., Wiktor Jr. J., Routti H., Bailey A., McFadden L., Brown Z., Beaugrand G. \& Grémillet D. 2010. Foraging distributions of little auks Alle alle across the Greenland Sea: implications of present and future Arctic climate change. Marine Ecology Progress Series 415, 283-293.

Karnovsky N.J., Kwasniewski S., Weslawski J.M., Walkusz W. \& Beszczynska-Möller A. 2003. Foraging behavior of little auks in a heterogeneous environment. Marine Ecology Progress Series 253, 289-303.

Kidawa D., Jakubas D., Wojczulanis-Jakubas K., Stempniewicz L., Trudnowska E., Keslinka-Nawrot L. \& Błachowiak-Samołyk K. 2015. Parental efforts of an Arctic seabird, the little auk Alle alle, under variable foraging conditions. Marine Biology Research 11, 349-360. 
Konarzewski M., Taylor J.R.E. \& Gabrielsen G.W. 1993. Chick energy requirements and adult energy expenditures of dovekies (Alle alle). The Auk 110, 343-353.

Koszteyn J., Timofeev S., Węsławski J.M. \& Malinga B. 1995. Size structure of Themisto abyssorum Boeck and Themisto libellula (Mandt) populations in European Arctic seas. Polar Biology 15, 85-92.

Kwasniewski S., Gluchowska M., Jakubas D., WojczulanisJakubas K., Walkusz W., Karnovsky N.J., BlachowiakSamolyk K., Cisek M. \& Stempniewicz L. 2010. The impact of different hydrographic conditions and zooplankton communities on provisioning little auks along the west coast of Spitsbergen. Progress in Oceanography 87, 72-82.

Masello J.F., Mundry R., Poisbleau M., Demongin L., Voigt C.C., Wikelski M. \& Quillfeldt P. 2010. Diving seabirds share foraging space and time within and among species. Ecosphere 1, 1-20.

Mehlum F. \& Gabrielsen G.W. 1993. The diet of High Arctic seabirds in coastal and ice-covered, pelagic areas near the Svalbard Archipelago. Polar Research 12, 1-20.

Moe B., Stempniewicz L., Jakubas D., Angelier F., Chastel O., Dinessen F., Gabrielsen G.W., Hanssen F., Karnovsky N.J., Rønning B., Welcker J., Wojczulanis-Jakubas K. \& Bech C. 2009. Climate change and phenological responses of two seabird species breeding in the High-Arctic. Marine Ecology Progress Series 393, 235-246.

Nilsen F., Cottier F., Skogseth R. \& Mattsson S. 2008. Fjordshelf exchanges controlled by ice and brine production: the interannual variation of Atlantic Water in Isfjorden, Svalbard. Continental Shelf Research 28, 1838-1853.

Pedersen C.E. \& Falk K. 2001. Chick diet of dovekies Alle alle in northwest Greenland. Polar Biology 24, 53-58.

Planque B. \& Batten S.D. 2000. Calanus finmarchicus in the North Atlantic: the year of Calanus in the context of interdecadal change. ICES Journal of Marine Science 57, 1528-1535.

Saloranta T.M. \& Svendsen H. 2001. Across the Arctic front west of Spitsbergen: high-resolution CTD sections from 1998-2000. Polar Research 20, 174-184.

Scott C.L., Falk-Petersen S., Sargent J.R., Hop H., Lønne O.J. \& Poltermann M. 1999. Lipids and trophic interactions of ice fauna and pelagic zooplankton in the marginal ice zone of the Barents Sea. Polar Biology 21, 65-70.

Seifert N. 2007. Foraging behaviour and spatial distribution of the High Arctic seabird little auk (Alle alle) along the west coast of Spitsbergen. Diploma thesis, Ernst Moritz Arndt Universität Greifswald and Norwegian Polar Institute.
Steen H., Vogedes D., Broms F., Falk-Petersen S. \& Berge J. 2007. Little auks (Alle alle) breeding in a High Arctic fjord system: bimodal foraging strategies as a response to poor food quality? Polar Research 26, 118-125.

Stempniewicz L. 2001. Alle alle little auk. The Journal of the Birds of the Western Palearctic 3, 175-201.

Stempniewicz L., Błachowiak-Samołyk K. \& Węsławski J. M. 2007. Impact of climate change on zooplankton communities, seabird populations and arctic terrestrial ecosystem-a scenario. Deep Sea Research Part II: Topical Studies in Oceanography 54, 2934-2945.

Trudnowska E., Sagan S., Kwasniewski S., Darecki M. \& Blachowiak-Samolyk K. 2015. Fine-scale zooplankton vertical distribution in relation to hydrographic and optical characteristics of the surface waters on the Arctic shelf. Journal of Plankton Research 37, 120-133.

Vogedes D., Eiane K., Båtnes A.S. \& Berge J. 2014. Variability in Calanus spp. abundance on fine- to mesoscales in an Arctic fjord: implications for little auk feeding. Marine Biology Research 10, 437-448.

Wakefield E.D., Bodey T.W., Bearhop S., Blackburn J., Colhoun K., Davies R., Dwyer R.G., Green J.A., Grémillet D., Jackson A.L., Jessopp M.J., Kane A., Langston R.H.W., Lescroël A., Murray S., Le Nuz M., Patrick S.C., Péron C., Soanes L.M., Wanless S., Votier S. C. \& Hamer K.C. 2013. Space partitioning without territoriality in gannets. Science 341, 68-70.

Wanless S. \& Harris M.P. 1993. Use of mutually exclusive foraging areas by adjacent colonies of blue-eyed shags (Phalacrocorax atriceps) at South Georgia. Colonial Waterbirds 16, 176-182.

Welcker J., Beiersdorf A., Varpe Ø. \& Steen H. 2012. Mass fluctuations suggest different functions of bimodal foraging trips in a central place forager. Behavioral Ecology 23, 1372-1378.

Weslawski J.M., Koszteyn J., Kwasniewski S., Stempniewicz L. \& Malinga M. 1999. Summer food resources of the little auk, Alle alle, in the European Arctic seas. Polish Polar Research 20, 387-403.

Weslawski J.M., Kwasniewski S., Stempniewicz L. \& Blachowiak-Samolyk K. 2006. Biodiversity and energy transfer to top trophic levels in two contrasting Arctic fjords. Polish Polar Research 27, 259-278.

Wojczulanis K., Jakubas D., Walkusz W. \& Wennerberg L. 2006. Differences in food delivered to chicks by males and females of little auks (Alle alle) on South Spitsbergen. Journal of Ornithology 147, 543-548. 